\title{
KEMATANGAN EMOSI DAN TINGKAT KECEMASAN \\ PERSALINAN PERTAMA USIA 17-21 TAHUN \\ DI KECAMATAN CANDI SIDOARJO
}

\author{
Effy Wardati M, S.Psi \\ (Dosen Fakultas Psikologi Umsida) \\ Yeni
}

\begin{abstract}
Abstrak
The background of this research by the researcher's curiosity about the level of emotional maturity and anxiety experienced by mothers who gave birth for the first time at age 17-21 years.

The purpose of this study is to determine whether there is a significant correlation between the level of emotional maturity level of anxiety at first birth mothers 17-21 years of age and indicators of what the most dominant influence of emotional maturity and high levels of anxiety.

Based on the analysis of obtained results of product moment correlation coefficient rxy 'correlation with $p=-0.167(0.257)>0.05$. this means that relations between the two variables are not significant. Supported also by results of interviews with the related subject of research and data in the field, says that not only emotional maturity factors that influence the level of anxiety a person in the first childbirth, but also the factor of family support, especially husbands and mothers, information about pregnancy and labor that they could get from print and electronic media and the internet which can be accessed with ease, some from their participation in the exercise group became pregnant, briefing the local health clinic doctor or midwife about childbirth and the high level of religiosity. All this is another factor which also makes the low level of anxiety to face the first delivery in mothers 17-21 years of age.
\end{abstract}

Key word : emotional maturity, anxiety at first birth

\section{Latar Belakang}

Kehamilan dan persalinan adalah salah satu rantai kejadian dalam perkembangan manusia dari lahir sampai mati. Pasangan muda biasanya tidak menganggap remeh kehamilan pertamanya, hal ini dikarenakan dalam situasi seperti ini pasangan muda dituntut menjalani kehidupan yang berbeda, yang lebih banyak membutuhkan tanggung jawab daripada sebelumnya. Terutama bagi wanita, tuntutan keadaan bagi wanita agar berperan sebagai ibu menjadikannya harus berlaku hati-hati dan selalu penuh tanggung jawab.

Dalam Rencana Strategis Nasional 2001-2010 dalam konteks
Rencana Pembangunan Kesehatan Menuju Indonesia Sehat 2010, dirumuskan Making Pregnancy Safer dengan visi "Kehamilan dan persalinan di Indonesia berlangsung aman, serta bayi yang dilahirkan hidup dan sehat". Salah satu sasarannya adalah menurunkan angka kematian maternal yang masih tinggi yaitu 334/100.000 kelahiran hidup menjadi 125/100.000 kelahiran hidup pada tahun 2010 (Saifuddin, 2002:76). Salah satu penyebab masih tingginya angka kematian maternal atau ibu di Indonesia adalah tingkat kecemasan ibu menjelang persalinan, terutama pada persalinan pertama. 
Menjelang persalinan sebagian besar ibu merasa cemas menghadapi persalinannya, apalagi bagi yang pertama kali atau primipara (Manuaba, 2000:72). Proses persalinan adalah saat yang menegangkan dan $m$ encemaskan bagi perempuan dan keluarga (Januadi, 2004:88). Tidak jarang perasaan cemas tersebut sudah dirasakan sebelum proses persalinan berlangsung. Hal ini dikarenakan persepsi persalinan yang tertanam di benak kebanyakan calon ibu sangat menakutkan. Banyak cerita orangorang sekitar yang pernah mengalaminya, mereka menggambarkan persalinan secara menakutkan, hal ini dapat menambah rasa cemas calon ibu, terutama ketika waktu persalinan tiba.

Telah dilakukan berbagai penelitian tentang Kecemasan Persalinan Pertama sebagaimana yang dilakukan oleh Suhartatik (2004:64) dengan judul "Hubungan Antara Keajegan Membaca Al-Qur'an dengan Tingkat Kecemasan Menjelang Persalinan di Daerah Kepanjen Malang." Penelitian ini merupakan studi tentang tingkat kecemasan para ibu di daerah Kepanjen Malang. Hasil penelitian ini menunjukkan bahwa $80 \%$ responden merasa cemas ketika akan menghadapi persalinan pertama. Hal ini ditunjukkan dengan adanya beberapa tanda kecemasan antara lain gejala fisik berupa mengeluarkan keringat yang sangat banyak, sering pusing, tingginya suhu badan, gatal-gatal pada daerah perut dan sering buang air besar. Selain itu terdapat beberapa perilaku yang oleh subjek, antara lain melampiaskan rasa marah pada orang lain, pergi ke suatu tempat untuk mencari hiburan, bercerita dengan teman atau orang terdekat, beristirahat dan mengurang diri di dalam kamar.
Berkaitan dengan pernikahan usia muda yaitu antara 17-21 tahun, dimana peran gadis remaja selanjutnya adalah menghadapi kehamilan, persalinan pertama dan merawat anak. Usia yang sangat muda memungkinkan timbulnya kekurangmatangan emosi sehingga banyak ibu-ibu muda yang mengalami kesulitan dalam mengatasi kecemasan yang timbul pada saat proses persalinan yang pertama kalinya. Bagaimanakah kondisi psikis serta perasaan yang dialami oleh calon ibu dalam menghadapi persalinan pertama terutama berkaitan dengan kecemasan yang dialaminya? Adakah hubungan antara kematangan emosi dengan tingkat kecemasan persalinan pertama pada usia 17-21 tahun di Kecamatan Candi Sidoarjo? Pertanyaanpertanyaan inilah yang menarik bagi penulis dan akan dicoba untuk dijawab dalam penelitian ini.

\section{Tinjauan Pustaka}

1. Ibu Usia 17-21 Tahun

a. Pengertian usia 17-21 tahun pada wanita

Jika dilihat dari periode perkembangan, usia antara 17-21 tahun masih tergolong dalam periode remaja atau adolencence, terutama remaja akhir. Adolencence atau remaja berasal dari kata Latin adolencere yang berarti tumbuh atau tumbuh menjadi dewasa. Istilah seperti yang dipergunakan saat ini merupakan arti yang lebih luas mencakup kematangan mental, emosional, sosial dan fisik.

Menurut Mappiare (1999:34) adalah masa yang berlangsung dari usia 17 
sampai 21 tahun. Begitu pula dengan pendapat L.C.T. Bigot, Ph. Kohnstam dan B.G. Palland (dlam Mapiare, 1999:35), ahli Psikologi berkebangsaan Belanda mengemukakan pembagian masa kehidupan dimana masa adolencence antara usia 1821 tahun, sedangkan Hurlock (2002:249) mengatakan masa remaja antara rentang 13-21 tahun yang dibagi dalam masa remaja awal usia 13 atau 14 tahun sampai 17 tahun dan remaja akhir usia 17 sampai 21 tahun. Sedangkan Priyanto (dalam Mapiare, 1999:38) menyebutkan bahwa rentang usia antara 13-21 tahun sebagai masa remaja.

b. Ciri-ciri wanita di usia 17-21 tahun.

Dalam periode ini terjadi proses penyempurnaan pertumbuhan fisik dan pertumbuhan aspek psikis yang telah dimulai sejak masa sebelumnya. Mereka menjadi wanita muda secara penuh atau "young women". Menurut Mappiare (1999:37) menyatakan pada masa ini terdapat beberapa ciri khas yaitu:

1) Stabilitas mulai timbul dan meningkat

2) Citra diri dan sikap pandangan

3) Menghadapi masalahnya

c. Pertumbuhan dan perkembangan wanita usia 17-21 tahun.

Sifat satu sifat dan ciri penting dari pertumbuhan dan perkembangan remaja adalah dicapainya keadan sempurna bagi beberapa aspek pertumbuhan dan perkembangan yang menunjukkan kesiapan atau kematangan untuk memasuki masa dewasa. Menurut Hurlock (2002:298) bahwa pada usia 18 tahun bagi wanita keadaan tinggi badan mengalami pertumbuhan yang lambat bekebalikan dengan penambahan berat yang lebih cepat.

Pertumbuhan fisik yang lain menjadi sempurna adalah bentuk wajah yang simetris, bentuk bahu yang berimang dengan panggul dan anggota badan yang lain. Perkembangan perilaku seks remaja merupakan akibat langsung dari kematangan atau kemasakan kelenjarkelenjar seks. Kehidupan moral remaja dalam hubungannya dengan pengaruh kuat bekerjanya kelenjar seks, tidak jarang menimbulkan konflik dalam diri mereka. Antara dorongan seks dengan pertimbangan moral sering kali bertentangan.

Beberapa ahli mengatakan bahwa sikap remaja akhir bisa dikatakan relatif stabil. Itu berarti rasa senang atau tidak senagn terhadap sesuatu didasarkan oleh hasil pemikirannya sendiri walaupun masih sering digoyahkan pendiriannya oleh orang tua mereka. Sikap yang kuat dlam masa remaja akhir adalah tertutup terhadap orang dewasa khususnya dalam pemecahan persoalan 
yang dihadapi. Hal ini disebabkan adanya keinginan untuk menunjukkan bahwa mereka mampu memecahkan persoalannya sendiri.

\section{Kecemasan}

a. Pengertian Kecemasan James (dalam Arnot, 2006:68) mengatakan bahwa perempuan lebih mudah dipengaruhi oleh tekanantekanan lingkungan daripada laki-laki. Perempuan juga lebih cemas, kurang sabar, dan mudah mengeluarkan air mata. Lebih lanjut lagi dalam berbagai studi kecemasan secara umum, menyatakan bahwa perempuan lebih cemas daripada laki-laki.

Kecemasan adalah tertentu yang mengancam dan merupakan hal yang normal terjadi menyertai perkembangan, perubahan dan pengalaman baru yang belum pernah dilakukan sehingga menjadi pengalaman subjektif yang tidak menyenangkan berbentuk ketegangan, kegelisahan, tertekan, dan penghambat hubungan interpersonal. Secara psikologis yang tampak seperti perasaan gelisah, kecenderungan berfikir bahwa keadaan semakin bertambah buruk, emosi yang tidak stabil, sangat mudah tersinggung dan marah, sering dalam keadaan excited atau mudah gelisah. Perempuan lebih mudah cemas daripada laki-laki.

b. Sumber Penyebab

Defferenbacher dan Hazaleus (dalam Ghufron dan Rini, 2010:143) mengemukakan bahwa sumber penyebab kecemasan meliputi hal-hal di $b$ awah ini:

1) Kekhawatiran (worry) merupakan pikiran negatif tentang dirinya sendiri, seperti perasaan negatif bahwa ia lebih jelek dibandingkan dengan teman-temannya.

2) Emosionalitas (imosionality) sebagai reaksi diri terhadap rangsangan saraf otonomoi, seperti jantung berdebar-debar, keringat dingin, dan tegang.

3) Gangguan dan hambatan dalam menyelesaikan tugas (task generated interference) merupakan kecenderungan yang dialami seseorang yang selalu tertekan karena pemikiran yang rasional terhadap tugas.

c. Bentuk-bentuk Kecemasan

Berdasarkan

pembagian para ahli, kecemasan dibagi menjadi:

1) Menurut Freud (dalam Alwisol, 2009:22-23) ada tiga macam kecemasan yaitu:

a) Kecemasan Realistik

b) Kecemasan Neurotik

c) Kecemasan Moral

2) Lahey \& Cirinero (2001:192-195), menyebutkan jenis-jenis 
kecemasan berdasarkan sifatnya adalah:

a) Kecemasan bersifat asertif

b) Kecemasan bersifat mengganggu

c) Kecemasan bersifat psikofisiologis

3) Lazarus (dalam Ghufron dan Rini, 2010:142) membedakan kecemasan menjadi dua, yaitu:

a) State anziety

b) Trait anxiety

d. Ciri-ciri Kecemasan

Menurut Maramis (2001:93), ciri atau gejala kecemasan sering ditandai dengan munculnya gejala yang bersifat somatik atau fisik, psikologis maupun behavior atau perilaku, yaitu:

1) Ciri-ciri somatik atau fisik

2) Ciri-ciri psikologis

3) Ciri-ciri behavior atau perilaku.

e. Teori-teori Kecemasan

Berbagai teori telah
dikembangkan menjelaskan asal kecemasan antara lain teori psikoanalisis, interpersonal, teori perilaku (Stuart dan Sudeen, 2000:162).

1) Teori psikoanalisis

2) Teori interpersonal

3) Teori perilaku

4) Teori keluarga

5) Teori biologi

f. Dinamika Kecemasan

Menurut Ghufron (2010:142) dinamika kecemasan ditinjau dari landasan teori ada beberapa jenis, antara lain:

1) Ditinjau dari teori psikoanalisa, kecemasan dapat disebabkan oleh adanya tekanan buruk perilaku masa lalu serta adanya gangguan mental.

2) Ditinjau dari teori kognitif, kecemasan terjadi karena adanya evaluasi diri yang negatif. Perasaan negatif tentang kemampuan yang dimilikinya dan orientasi diri yang negatif.

3) Ditinjau dari teori humanistik, maka kecemasan merupakan kekhawatiran tentang masa depan, yaitu khawatir pada apa yang akan dilakukan.

g. Faktor Penyebab Kecemasan Faktor penyebab
timbulnya menurut Collins (dalam Susabda, 2001:87) bahwa kecemasan timbul karena adanya:

1) Threat (ancaman) baik ancaman terhadap tubuh, jiwa atau psikisnya (seperti kehilangan kemerdekaan, kehilangan arti kehidupan, dll) maupun ancaman terhadap eksistensinya (seperti kehilangan hak).

2) Conflict (pertentangan) yaitu karena adanya dua keinginan yang keadaannya bertolak belakang, hampir setiap dua konflik, dua alternatif atau lebih yang masing-masing mempunyai sifat approach dan avoidance.

3) Fear (ketakutan), kecemasan sering timbul karena ketakutan akan 
sesuatu, ketakutan akan kegagalan menimbulkan kecemasan, ketakutan akan kegagalan dalam menghadapi ujian atau ketakutan akan penolan menimbulkan kecemasan setiap kali harus berhadapan dengan orang lain.

4) Unfulled Need (kebutuhan yang tidak terpenuhi), dimana kebutuhan manusia begitu kompleks dan bila ia gagal untuk memenuhinya maka timbullah kecemasan.

h. Tingkatan Kecemasan

Menurut Stuart dan Sudden (2000:164) kecemasan dibagi menjadi empat tingkatan, yaitu:

1) Kecemasan ringan

Kecemasan yang dialami berhubungan dengan ketegangan dalam kehidupan sehari-hari dan menyebabkan seseorang menjadi waspada dan meningkatkan lahan persepsinya. Kecemasan pada tingkat ini dapat memotivasi individu untuk belajar dan menghasilkan kreativitas.

2) Kecemasan sedang

Kecemasan pada tingkat ini individu lebih memfokuskan hal penting saat ini dan mengesampingkan yang lain sehingga mempersempit lahan persepsi.

3) Kecemasan berat
Kecemasan pada tingkat ini berhubungan dengan adanya ketakutan dan teror, rincian terpecah dari proporsinya karena mengalami kehilangan kondisi. Individu tidak mampu melakukan sesuatu dengan pengarahan.

4) Panik

Kondisi ini berhubungan dengan adanya ketakutan dan terpecahnya konsentrasi karena mengalami kehilangan kendali. Individu tidak mampu untuk melakukan sesuatu walaupun dengan pengarahan. Menurutnya respon untuk berhubungan dengan orang lain menjadi disforsi persepsi dan kehilangan pikiran yang rasional. Tingkah laku panik ini mendukung kehidupan individu.

i. Faktor-faktor yang mempengaruhi tinggi rendahnya kecemasan.

Faktor-faktor yang mempengaruhi tinggi rendahnya kecemasan menurut Ramaiah (2003:59) adalah:

1) Lingkungan

Lingkungan atau sekitar tempat tinggal mempengaruhi pola pikir tentang diri sendiri dan orang lain.

2) Emosi yang ditekan Kecemasan dapat terjadi jika tidak mampu melakukan jalan keluar seperti ingin marah atau 
frustasi dalam jangka waktu yang lama sekali.

3) Sebab-sebabb fisik

Pikiran dan tubuh senantiasa saling interaksi dapat menyebabkan timbulnya kecemasan seperti sewaktu pulih dari suatu penyakit, keadaan hamil, menghadapi tugas-tugas, menghadapi ujian, dan kondisi yang lainnya. Selama mengalami kondisi ini perubahanperubahan yang lazim akan timbul dan dapat menyebabkan timbulnya perasaan cemas.

3. Kecemasan pada persalinan pertama

Bagi sebagian wanita, kehamilan dan persalinan pertama merupakan suatu kebanggaan sebagai wujud kesempurnaan sedangkan sebagian lain menganggapnya sebagai hambatan bagi kegiatan yang dilakukannya (Kartono, 2000:87). Banyak orang yang mengatakan "menantang maut" sebagai ungkapan untuk menggambarkan perjuangan wanita saat menjalani proses persalinan. Meskipun termasuk hal wajar yang harus dihadapi wanita, tetapi banyak wanita atau calon ibu merasakan ketakutan terutama pada kelahiran pertama. Karena semuanya merupakan pengalaman baru yang belum pernah dirasakan sebelumnya. Apalagi ibu yang tergolong masih remaja, dia harus bisa mengalahkan perasaan takut, perasaan tidak siap untuk menjalaninya karena ini sudah menjadi kodrat bagi seorang wanita.

Dibutuhkan waktu 37 minggu untuk menanti seorang bayi dan hanya beberapa jam untuk mengeluarkannya ke dunia, namun demikian jam-jam itulah yang tampaknya menyita seluruh pikiran dan perasaan para wanita hamil. Menurut Arlene (dalam Setiyowahyuni, 2007:16) lebih banyak pertanyaan, ketakutan dan kekhawatiran yang besar mengenai proses kelahiran dan persalinan daripada tentang aspek kehamilan lainnya, terutama pada wanita yang baru pertama kali mengalaminya.

Beberapa pertanyaan yang muncul antara lain:

a. Kapan mereka akan mulai dan yang penting lagi kapan mereka akan selesai?

b. Apakah saya sanggup menahan nyeri?

c. Bagaimana jika proses persalinan saya berhenti?

Dari beberapa pertanyaan di atas jelas terlihat ada rasa takut dan perasaan cemas yang dirasakan oleh wanita yang akan menghadapi persalinan pertama. Perasaan cemas yang ada dalam diri wanita saat menghadapi persalinan, bila berada pada taraf normal tentunya tidak akan menimbulkan dampak yang serius selama proses persalinan. Namun karena perasaan cemas tersebut ada kalanya kurang disadari oleh wanita itu maka bisa jadi perasaan cemas bertambah lama di dalam dirinya. Lama-kelamaan kecemasan ini akan memiliki frekuensi dan intensitas yang semakin tinggi.

Dengan semakin dekatnya jadwal persalinan, terutama pada 
persalinan pertama wajar timbul perasaan cemas ataupun takut, di satu sisi ingin segera melepaskan beban dari perut yang membesar, namun di lain pihak timbul kekhawatiran tersendiri. Bebearpa hal yang dicemaskan oleh ibu saat mendekati persalinan antara lain:
a. Apakah bisa menjalani persalinan tanpa suatu halangan?
b. Apakah segala persiapan selama ini sudah memadai?
c. Keadaan bayi
d. Apakah saya bisa menjadi ibu yang baik?

Adapun akibat ataupun dampak yang diberikan oleh kecemasan dan ketakutan secara umum adalah serangan jantung. Hal tersebut disebabkan oleh kerja hormon adrenalin yang meningkatkan denyut jantung. Jantung kita diibaratkan sebagai pompa, sedangkan kecemasan ataupun ketakutan diibaratkan sebagai tekanan yang dapat membuat pompa bergerak sesuai kebutuhan (Hogg, 2007:98).

Seorang ibu yang akan bersalin pertama kali biasanya memiliki kecemasan berupa kebingungan dan mengembangkan reaksi kecemasan terhadap cerita mengerikan (Kartono, 2000:58). Sebenarnya menurut Lowe (dalam Jameson, 2003:173), kecemasan akan ketidaktahuan tentang persalinan ini adalah sesuatu yang normal. Meski demikian, Hobel (dalam Jameson, 2003:174) menyatakan bahwa stres dapat menimbulkan beberapa reaksi dalam tubuh ibu hamil. Kecemasan yang terjadi terus menerus dapat menyebabkan syaraf simpatetik memacu kerja pernafasan paru-paru guna mengalirkan oksigen ke jantung sehingga jantung dapat dengan kuat memompa darah guna dialirkan keseluruh tubuh, termasuk yang dialirkan kedalam janin melalui plasenta dalam rahim ibu. Kondisi ini berarti menekan janin dengan akibatnya janin menjadi tergoncang seolaholah didesak untuk keluar dari rahim, yang dapat menyebabkan kelahiran bayi prematur (Dariyo, 2001:66).

4. Kematangan Emosi
a. Pengertian
Kematangan Emosi

Kematangan emosi merupakan kedewasaan dari segi emosional dalam artian individu tidak lagi terombang-ambing oleh motif kekanak-kanakan. Menurut Chaplin (2008:165) emotional maturity adalah suatu keadaan atau kondisi mencapai tingkat kedewasaan dari perkembangan emosi dan karena itu pribadi yang bersangkutan tidak lagi menampilkan pola emosional yang tidak pantas. Menurut pandangan Skinner (dalam http://Wangmuba.com, 2009) esensi kematangan emosi melibatkan kontrol emosi yang berarti bahwa seseorang mampu memelihara perasaannya, dapat meredam perasaannya, dapat meredam emosinya, meredam balas dendam dalam kegelisahannya, dan tidak mudah berubah pendirian.

Sedangkan Yusuf (2001:115), mendefisikan kematangan emosi adalah kemampuan individu untuk 
dapat bersikap toleran, merasa nyaman, mempunyai kontrol diri sendiri, perasaan mau menerima dirinya sendiri dan orang lain, serta mampu menyatakan emosinya secara konstruktif dan kreatif. Perkembangan emosi dalam diri seseorang akan mengalami peningkatan menuju kematangan emosi seiring dengan tahap-tahap perkembangan yang dialami.

Kematangan emosi adalah orang yang telah mencapai tingkat kedewasaan dari perkembangan emosionalnya, yaitu emosi yang stabil tidak meledakletak, mampu mengendalikan atau mengontrol emosi dan mewujudkannya melalui respon emosional yang baik dengan tanggung jawab yang baik pula. Semakin berkembang tingkat kedewasaan seseorang, maka semakin mampu pula individu tersebut untuk memberikan respon emosi yang baik sehingga dapat mengatasi tekanan kehidupan yang dihadapi.

b. Ciri-ciri Kematangan Emosi Hurlock (2002:312) menyebutkan ciri-ciri kematangan emosi adalah sebagai berikut:

1) Emosi terkendali

2) Emosi terarah

3) Memiliki rasa tanggung jawab

4) Emosi terbuka lapang Feinberg, 2004 (dalam http://tempatkita.blogspot.co m) ada beberapa karakteristik atau tanda mengenai kematangan emosi seseorang yaitu kemampuan seseorang untuk dapat menerima dirinya sendiri, menghargai orang lain, menerima tanggung jawab, percaya pada diri sendiri, sabar dan mempunyai rasa humor.

Kriteria kematangan emosi menurut Overstreet (dalam Puspitasari, 2002:36), dibagi menjadi enam yaitu:

1) Sikap untuk belajar

2) Memiliki rasa tanggung jawab

3) Memiliki kemampuan untuk berkomunikasi dengan efektif

4) Memiliki kemampuan untuk menjalin hubungan sosial

5) Bealih dari egosentrisme ke sosiaosentrisme

6) Falsafah hidup yang terintegrasi

c. Faktor-faktor Kematangan Emosi

$$
\text { Menurut Young }
$$$$
\text { (2000, 345-353) }
$$
menyebutkan faktor-faktor yang berpengaruh terhadap perkembangan kematangan emosi seseorang yaitu:

1) Faktor fisik

2) Faktor lingkungan

3) Faktor individu

4) Faktor pengalaman

5) Pola-pola kontrol terhadap emosi

6) Intelegensi

7) Pola asuh orang tua

8) Temperamen

9) Usia

$$
\text { Rogers (2000:101- }
$$

105) menguraikan beberapa faktor pengaruh kematangan emosi antara lain adalah: 
1) Keluarga

2) Jenis Kelamin

3) Televisi

Berdasarkan pendapat diatas dapat disimpulkan bahwa faktor yang mempengaruhi kematangan emosi antara lain adalah usia, temperamen, pola asuh orang tua,l intelegensia, keluarga, lingkungan, jenis kelamin, media televisi, pengalaman serta individu itu sendiri.

d. Aspek-aspek Kematangan Emosi

\begin{tabular}{lr}
\multicolumn{1}{c}{ Menurut } & Young \\
(2006:289), & aspek \\
kematangan emosi & adalah \\
sebagai berikut: &
\end{tabular}

1) Kemampuan untuk beradaptasi dengan realitas.

2) Kemampuan untuk beradaptasi dengan perubahan.

3) Dapat mengontrol gejala emosi yang mengarah pada kemunculan kecemasan.

4) Kemampuan untuk menemukan kedamaian jiwa dari memberi dibandingkan dengan menerima.

5) Konsisten terhadap prinsip, janji dan keinginan untuk menolong orang yang menglami kesulitan.

6) Dapat meredam instink negatif menjadi energi kreatif dan konstruktif.

7) Kemampuan untuk mencintai.

5. Persalinan
a. Pengertian Persalinan

Persalinan adalah proses alamiah ketika terjadi pembukaan mulut rahim serta pengeluaran janin dan plasenta dari uterus ibu (Maimunah, 2005:95). Menurut Januadi (2004:154) persalinan adalah proses pengeluaran hasil konsepsi yang dapat hidup dari dalam rahim melalui vagina ke dunia luar. Persalinan merupakan proses alami yang sudah berlangsung sejak manusia ada di muka bumi. Menurut WHO (Januadi, 2004:153) persalinan terjadi secara spontan, beresiko rendah pada awal persalinan dan tetap demikian selama proses kehamilan.

Perhatian dan aktivitas fisik yang didapat seorang ibu pada masa persalinan akan terus dikenang, terutama bagi mereka yang pertama kali melahirkan. Bila pengalaman itu menyenangkan, maka dpat jadi "modal" bagi lancarnya persalinan. Namun, bila yang terjadi adalah sebaliknya, biasanya itu akan menjadi pengalaman buruk yang akan membuat mereka jera, juga mengganggu proses melahirkan. Kendati penting, namun secara faktual banyak orang yang mengabaikan sisi kebutuhan psikis ibu saat 
persalinan dan lebih memperhitungkan

kesiapan fisik belaka.

b. Jenis Persalinan

Persalinan

$\begin{array}{lr}\text { terhadap } & \text { beberapa } \\ \text { macam, } & \text { antara lain } \\ \text { (dalam } & \text { Januadi, } \\ \text { 2004:149): } & \end{array}$

1) Persalinan spontan adalah jika

persalinan ini

berlangsung dengan

kekuatan ibu sendiri

dan melalui jalan lahir.

2) Persalinan bantuan adalah bila

persalinan dibantu dengan tenaga dari luar misalnya ekstrasi dengan forceps atau dilakukan section caesaria.

3) Persalinan anjuran adalah persalinan yang terjadi bila bayi cukup besar untuk hidup di luar, tetapi tidak sedemikian besarnya sehingga menimbulkan

kesulitan dalam persalinan.

c. Ciri-ciri Periode Prenatal Meskipun relatif singkat, periode prenatal mempunyai enam ciri, masing-masing ciri mempunyai akibat yang lambat pada perkembangan selama rentang kehidupan. Ciriciri itu adalah (Maimunah, 2005:97):

1) Pada saat ini sifatsifat bauran yang berfungsi sebagai dasar bagi perkembangan selanjutnya, diturunkan sekali untuk selamanya. Sementara itu kondisi-kondisi yang baik atau tidak baik sebelum atau ssudah kelahiran. Pada tingkat tertentu, dapat dan mungkin mempengaruhi sifatsifat fisik dan psikologis yang membentuk sifatsifat bawaan ini, perubahan-

perubahan yang terjadi bersifat kuantitatif dan kualitatif.

2) Kondisi-kondisi yang baik dalam tubuh ibu dpat menunjang perkembangan sifat bawaan. Sedangkan kondisi yang tidak baik dapat menghambat perkembangannya bahkan sampai mengganggu pola perkembangannya yang akan datang. Ada saatnya dalam rentang kehidupan sifat bawaan dapat mempengaruhi kondisi-kondisi lingkungan seperti halnya selama periode pranatal.

3) Jenis kelamin individu yang baru diciptakan sudah 
dipastikan pada saat

pembuahan dan

kondisi-kondisi

dalam tubuh ibu

tidak akan

mempengaruhinya,

sama halnya dengan

sifat bawaan.

Kecuali kalau

dilakukan

pembedahan dalam operasi perubahan

kelamin, jenis

kelamin individu

yang sudah

ditetapkan pada saat

pembuahan tidak

akan berubah.

Operasi semacam itu

sangat jarang

dilakukan dan hanya

sebagian kecil saja

berhasil.

4) Perkembangan dan pertumbuhan yang normal lebih banyak terjadi selama periode prenatal dibandingkan pada periode-periode lain dalam seluruh kehidupan individu. Selama sembilan bulan sebelum kelahiran, individu tumbuh dari sel kecil yang panjangnya sekitar 20 inchi dan beratnya rata-rata 7 pon. Diperkirakan bahwa selama masa itu berat badan bertambah sebelas juta kali. Demikian pula dengan perkembangan yang kelihatannya berlangsung begitu cepat.

5) Periode prenatal merupakan masa yang mengandung banyak bahaya, baik fisik maupun psikologis.

Meskipun tidak dapat diklaim bahwa periode ini merupakan periode yang paling berbahaya dalam seluruh rentang kehidupan, banyak yang percaya bahwa masa kanak-kanak lebih berbahaya, tetapi jelas bahwa periode ini merupakan masa dimana bahayabahaya lingkungan atau bahaya-bahaya psikologis dpat sangat mempengaruhi pola perkembangan selanjutnya atau bahkan dapat mengakhiri suatu perkembangan.

6) Periode prenatal merupakan saat dimana orang-orang yang berkepentingan membentuk sikapsikap pada diri individu yang baru diciptakan. Sikapsikap ini sangat mempengaruhi bagaimana individuindividu ini diperlakukan, terutama selama tahun-tahun pertama 
pembentukan

kepribadiannya.

Kelau sikap-sikap ini sangat bersifat emosional, maka hal ini dapat dan seringkali merusak keseimbangan ibu (mother's

homeostatis). Dan dengan demikian menganggu kondisikondisi di dalam tubuh ibu sangat penting bagi perkembangan normal dari individu yang baru diciptakan. (Hurlock, 2002:29).

d. Faktor-faktor yang mempengaruhi

Persalinan Normal

Terdapat

hubungan timbal balik dari faktor yang mempengaruhi seorang wanita dalam persalinan dan apakah hasil yang dicapai berhasil atau tidak yang melibatkan persalinan seorang bayi sehat melalui vagina.

Menurut Januadi (2004:156), ada tujuh faktor yang mempengaruhi jalannya persalinan normal yaitu:

1) Keadaan fisik umum dan emosional pasien

2) Besarnya janin

3) Presentasi janin

4) Kualitas dan jenis kontraksi uterus

5) Keadaan mulut rahim
6) Anatomi dan volume uterus

7) Arsitektur tulang panggul

6. Hubungan

Antara

Kematangan Emosi dan

Tingkat Kecemasan pada Persalinan Pertama Usia 1721 Tahun.

Perasaan cemas y ang ada dalam diri wanita saat menghadapi persalinan, bila berada pada taraf normal tentunya tidak akan menimbulkan dampak yang serius selama proses persalinan. Namun karena perasaan cemas tersebut ada kalanya kurang disadari oleh wanita itu maka bisa jadi perasaan cemas bertahan lama di dalam dirinya. Lamakelamaan kecemasan ini akan memiliki frekuensi dan intensitas yang semakin tinggi. Kecemasan yang terjadi terus menerus dapat menyebabkan reaksi yang berlebihan juga terhadap kondisi fisik dan psikis ibu.

Untuk itu dibutuhkan kematangan emosi agar seorang ibu tidak merasakan pada persalinan pertamanya, dimana hal ini membawa dampak yang baik terhadpa diri calon ibu sendiri maupun bagi bayinya. Kematangan melibatkan kondisi fisik dan psikis dimana seseorang harus mencapai tahap tertentu sehingga dapat dikatakan "matang" agar siap dalam menghadapi semua permasalahan kehidupan.

Menurut Badan

Koordinasi Keluarga

Berencana Nasional (1999) 
diharapkan seseorang menikah dan mempunyai anak pertama dalam kondisi:

1. Kematnagan atau kemampuan fisik (jasmani).

Yang ideal apabila seorang wanita telah berusia 20 tahun, sedangkan bagi laki-laki dianjurkan kalau sudah mencapai 25 tahun. Secara medis usia ini sudah dikatakan matang.

2. Kematangan atau kemampuan mental (psikis).

Yaitu seseorang yang telah mencapai

kedewasaan rohani dan telah mampu

menghadapi serta memecahkan masalah kehidupan secara mandiri.

3. Telah cukup mampu dalam masalah ekonomi atau keuangan.

Dengan kematangan yang cukup seseornag akan dapat memahami semua permasalahan yang ada terutama pada seorang wanita, dimana diharapkan sudah mengerti mengenai tugas dan kewajiban baik sebagai seorang wanita sendiri dan sebagai seorang istri, terutama sebagai seorang ibu. Sehingga sesuatu hal yang timbul tidak akan menyebabkan kegelisahan atau bahkan menimbulkan kecemasan tertentu.

\section{Metode Penelitian}

Berdasakan jenis data, penelitian ini merupakan penelitian kuantitatif, yaitu suatu penelitian dimana peneliti ingin mendapatkan data yang objektif, valid dan reliabel dengan menggunakan data kuantitatif. Data kuantitatif adalah data yang berbentuk angka atau data kualitatif yang diangkakan. Data kualitatif yang diangkakan misalnya terdapat dalam skala pengukuran (Sugiono, 2010:16).

Dalam penelitian ini peneliti menggunakan pendekatan survey dengan model korelasional, yaitu untuk mengetahui hubungan antar variabel dalam penelitian. Kerlinger (dalam Sugiono, 2010:17) mengemukakan bahwa penelitian survey adalah penelitian yang dilakukan pada populasi besar maupun kecil, tetapi data yang dipelajari adalah data dari sampel yang diambil dari populasi tersebut, sehingga ditemukan kejadian-kejadian relatif, distribusi dan hubungan-hubungan antar variabel, sosiologis maupun psikologis.

Subjek yang dijadikan responden pada penelitian ini memiliki karakteristik sebagai berikut:

1. Telah menikah

2. Ibu yang berusia antara 17-21 tahun

3. Mengalami persalinan anak pertama di usia tersebut di atas.

4. Saat ini berdomisili di daerah Kecamatan Candi, Sidoarjo.

1. Populasi

Populasi yang dipilih dalam penelitian ini adalah ibu yang telah menikah serta mengandung dan melahirkan anak pertama pada usia antara 17-21 tahun di Kecamatan Candi Sidoarjo yang keseluruhan populasinya berjumlah $48 \mathrm{ibu}$.

2. Sampel

Jumlah sampel yang digunakan dalam penelitian ini 
adalah sebanyak 48 ibu yang diambil dari 9 Desa di Kecamatan Candi. Menurut Arikunto (2006:134) apabila subjeknya kurang dari 100, lebih baik diambil semua sehingga penelitiannya merupakan penelitian populasi. Jadi populasi dalam penelitian ini keseluruhannya digunakan sebagai sampel penelitian.

\section{Analisis Data}

Subyek yang dijadikan responden pada penelitian ini memiliki karakteristik sebagai berikut:

1. Telah menikah

2. Hanya ibu yang berusia antara 1721 tahun saja.

3. Mengalami persalinan anak pertama di usia tersebut di atas.

4. Tidak dibedakan dari latar belakang pendidikan, ekonomi dan budaya.

5. Saat ini berdomisili di darah Kecamatan Candi, Sidoarjo.

Peneliti melakukan survei sebelum melakukan penelitian di daerah Kecamatan Candi, Sidoarjo untuk mengetahui adanya sampel yang akan diteliti dan kondisi para subjek apakah memungkinkan diadakan penelitian serta ada tidaknya masalah penelitian ini terjadi di daerah tersebut.

Penelitian dilakukan di Kecamatan Candi, Sidoarjo mulai tanggal 1 Juni 2010 hingga tanggal 12 Juli 2010. Hari pertama penelitian dimulai dari pukul 08.00-12.00 WIB dengan lokasi penelitian utama adalah di Rumah Sakit Bersalin (RSB) Buah Delima. Pada penelitian di RSB Buah Delima baru mendapatkan data tentang ibu yang melahirkan anak pertama di usia 17-21 tahun pada bulan Januari - Juni 2010 yaitu sejumlah 6 ibu. Hal ini dikarenakan untuk dapat sebelum tahun 2010 tidak bisa dikeluarkan selain dari segi waktu juga karena pertimbangan tertentu dari pihak RSB. Namun karena data partisipan yang diberikan RSB hanya 1 ynag berbeda di wilayah Kecamatan Candi sedangkan 5 yang lainnya berada di luar lokasi penelitian maka untuk selanjutnya peneliti hanya menghubungi partisipan yang sesuai lokasi penelitian yang sudah ditetapkan untuk selanjutnya pengisian angket dilakukan di rumah responden pada hari berikutnya (hari kedua) pada pukul 09.30 WIB sesuai kesepakatan karena kebetulan responden juga seornag ibu rumah tangga yang tidak bekerja.

Berlanjut hari ketiga dengan awal waktu penelitian yang sama dan berakhir sekitar pukul 14.00 WIB, tetapi lokasi utama penelitian difokuskan Puskesmas Kecamatan Candi, Sidoarjo. Peneliti berharap bisa mendapatkan responden dengan jumlah yang banyak, tapi ternyata informasi yang didapatkan peneliti hanyalah data ibu yang melakukan pemeriksaan pada kehamilan pertamanya. Hal ini karena di Puskesmas Kecamatan Candi hanya melayani pemeriksaan dan konsultasi kehamilan saja, sedangkan untuk tindakan persalinannya diarahkan ke bidan terdekat dari masing-masing desa, sehingga pada penelitian hari itu tidak mendapatkan satu responden pun yang benar-benar sesuai dengan kriteria.

Peneliti menentukan sikap untuk lebih "menjemput bola", yaitu dengan meminta data pada bidan desa di lokasi penelitian di atas. Penelitian ini pun dilakukan di 9 desa yang ada di Kecamatan Candi, Sidoarjo. Dari data yang didapatkan tersebut ditindak lanjuti dengan mendatangi rumah 
masing-masing ibu yang melahirkan anak pertamanya di usia 17-21 tahun untuk mengisi angket-angket penelitian. Dari 48 responden semua mengisi angket dengan benar dan sesuai petunjuk, jumlah angket yang disebarkan juga kembali semuanya. Kemudian peneliti melanjutkan langkah selanjutnya dengan membuat tabulasi dan menghitung data dengan menggunakan program SPSS 17.0 for Windows.

Berdasarkan analisis korelasi product moment diperoleh hasil koefisien korelasi $r_{x y}=-0,167$ dengan $\rho(0,257)>0,05$. Artinya hubungan kedua variabel tersebut tidak signifikan.

Berdasarkan hasil penelitian diketahui bahwa sebagian besar $(47,92 \%$ dan $31,25 \%)$ nilai variabel kematangan emosi berada pada kategori sedang dan tinggi. Kecemasan persalinan pertama sebagian besar berkategori sedang $(47,92)$ dan rendah $(31,25 \%)$.

Dari deskripsi data diketahui pernyataan teratas yang paling disukai atau disetujui dari pernyataanpernyataan pada angket kematangan emosi ini adalah pernyataan yang mengungkapkan memiliki kemampuan berkomunikasi dengan efektif dan rasa tanggung jawab. Bentuk komunikasi efektif dapat membantu ibu yang sedang menghadapi persalinan pertmanya untuk mengungkapkan perasaan dan keinginannya. Sang ibu hanya membutuhkan banyak dukungan terutama dari suami dan keluarga ketika akan menjalani proses persalinan. Di dukung pula dengan adanya rasa tanggung jawab yang besar sehingga bisa membantu ibu dalam membangun harga diri dan kompetensi.

Dua pernyataan teratas yang paling disukai atau disetujui dari pernyataan-pernyataan diangket kecemasan persalinan pertama adalah pernyataan yang mengungkapkan ciri perilaku, seperti perilaku menghindar dari masalah, ingin melarikan diri dari tempat tersebut dan perilaku dependen. Pdaa tabel tersebut juga terlihat faktor psikis banyak menjadi alterantif pilihan responden. Hal ini menunjukkan bahwa responden banyak mengalami kecemasan secara psikis, seperti munculnya rasa waswas, khawatir akan terjadi sesuatu yang tidak menyenangkan, tegang terus-menerus, tidak bisa berlaku santai, mudah marah, depresi, adanya perasaan tidak mampu, dan lain sebagainya.

\section{Hasil Penelitian dan Diskusi Hasil Penelitian}

Diketahui bahwa $\rho(0,257)>$ 0,05. Menurut Hadi (2000:54), nilai signifikansi $\rho>0,05$ dikelompokkan dalam kategori taraf signifikansi tidak signifikan. Dalam hipotesis hal ini menunjukkan bahwa tidak ada hubungan antara kematangan emosi dengan kecemasan persalinan pertama.

Hasil dari penelitian ini tidak mendukung hipotesis awal yang diajukan oleh peneliti. Semakin tinggi kematnagan emosi maka semakin rendah tingkat kecemasan persalinan pertama, atau sebaliknya semakin rendah tingkat kematangan emosi maka akan semakin tinggi tingkat kecemasan pada persalinan pertamanya. Melainkan semakin tinggi kematangan emosi tidak secara otomatis dan menyeluruh menurunkan kecemasan pada ibu dalam menghadapi persalinan pertamanya. Hal ini dimungkinkan karena banyak variabel atau faktor lain yang mempengaruhi kecemasan seorang ibu pada persalinan pertamanya yang tidak ikut diteliti dalam penelitian ini. 
Kemungkinannya antara lain faktor sosial (seperti pengaruh pendidikan atau pengajaran, dan berbagai tekanan sosial) faktor demografik, latar belakang psikososial istri, faktor intelektual atau latar belakang pendidikan istri, faktor pengalaman psikis, faktor lingkungan sosial, budaya, tingkat religiusitas dan ekonomi.

Sehingga dikarenakan ditolaknya hipotesis awal yang diajukan peneliti, peneliti kemudian mencoba mencari pemecahan jawaban dari pertanyaan penelitian pada bab I dengan mencari penyebab ditolaknya hipotesis awal dari beberapa faktor dan menggunakan analisis butir-butir pernyataan dari angket terbuka yang ada pada kuesioner penelitian ini. Selain itu peneliti juga memperkuat argumennya dengan menambahkan hasil wawancara terhadap subjek yang terkait dengan penelitian.

Berkaitan dengan hal tersebut peneliti berasumsi:

1. Persepsi subjek terhadap kecemasan pada persalinan pertama.

Pada penelitian ini kecemasan persalinan pertama yang diukur adalah kecemasan pada subjek setelah terjadinya persalinan pertama, bukan pada saat menjelang persalinan. Hal ini disebabkan karena keterbatasan peneliti dalam hal waktu dan kurangnya data yang mendukung dalam menentukan subjek yang terkait dengan penelitian.

2. Tinjauan jumlah sampel

Jumlah sampel pada penelitian ini adalah keseluruhan populasi yaitu $48 \mathrm{ibu}$, hal ini dirasa peneliti mempengaruhi data yang didapatkan. Arikunto (2007:95) berpendapat bila jumlah anggota subjek dalam populasi hanya 100 sampai 150 dan dalam pengumpulan data peneliti menggunakan angket, sebaiknya subjek sejumlah itu diambil seluruhnya. Hal ini menunjukkan bahwa jumlah sampel dalam penelitian ini terlalu sedikit, sehingga memungkinkan hasil yang diinginkan tidak sesuai dengan hipotesa.

3. Tinjauan terhadap alat ukur atau skala.

Meskipun dari pengkategorian diperoleh kriteria kematangan emosi yang terdiri dari 6 aspek seperti sikap untuk belajar, memiliki rasa tanggung jawab, memiliki kemampuan untuk berkomunikasi efektif, memiliki kemampuan untuk menjalin hubungan sosial, beralih dari egosentris ke sosiosentrisme dan falsafah hidup yang terintegrasi yang digunakan untuk mengungkap kematangan emosi pada ibu yang mengalami persalinan pertama, sedangkan jika dilihat secara luas kematangan emosi ini memiliki aspek lain yang harus diperhatikan. Peneliti berasumsi bahwa skala yang digunakan belum mengungkap secara mendalam variabel bebas yang digunakan, sehingga harus ada spesifikasi dalam pengukuran yang berkaitan dengan kematangan emosi, misalnya adanya beberapa karakteristik khusus yang mengarah pada perilaku tertentu. Berikut dijelaskan beberapa bentuk karakteristik kematangan emosi yang sifatnya lebih mendalam dan bisa mengarah pada perilaku tertentu:

a. Karakteristik kematangan emosi menurut Lindgreen dan 
Byrne (dalam Sholichah, 2003:41) yang lebih mengarah pada perilaku emosi yang menunjukkan derajat penguasaan penurunan emosi, antara lain : kontrol, diferensiasi, perbedaan persepsi, intensitas, dan kontrol lingkungan.

b. Karakteristik kematangan emosi menurut Tussing (dalam Sholichah, 2003:47) yang lebih mengarah pada keterarahan emosi, antara lain: Lebih sadar akan realitas kehidupan, memiliki sifat emosi yang tetap, mempunyai tingkat pengenalan tertentu pada orang lain, kemampuan mengekspresikan emosi menurut keadaan, dan kesesuaian mendalam antara cita-cita dan prestasi.

c. Karakteristik kematangan emosi menurut Tussing (dalam Sholichah, 2003:49) yang lebih mengarah pada pertimbangan emosi, antara lain : emosi mempunyai waktu tertentu dan emosi sebagai bagian dari hidup.

d. Karakteristik kematangan emosi menurut Jersild (dalam Sholichah, 2003:52) yang lebih mengarah pada pemahaman emosi, antara lain : kemampuan untuk menggunakan sumber-sumber emosional, kemampuan untuk mendapatkan kepuasan dari sesuatu yang menyenangkan, kemampuan untuk mencintai dan menerima cinta, kemampuan untuk mengalami kemarahan ketika dihadapkan dengan frustasi yang meningkatkan rasa tenang, menerima dan menyadari arti ketakutan yang timbul ketika menghadapi sesuatu yang menakutkan dan meraih apa yang sudah diberi kehidupan.

e. Karakteristik kematangan emosi menurut Hollingsworth (dalam Sholichah, 2003:53) yang lebih mengarah pada pengontrolan emosi, antara lain : kemampuan gradasi atau tingkat respon emosi, kemampuan menunda emosi, dan perlakuan rasa mengasihani diri.

f. Karakteristik kematangan emosi menurut Hurlock (dalam Sholichah, 2003:54) yang lebih mengarah pda penyesuaian emosi, antara lain: socially approved control (kontrol yang diakui secara umum), selfknowledge (pengetahuan diri), use critical mental faculties (penggunaan kemampuan kritik mental).

g. Karakteristik kematangan emosi menurut Vogel (dalam Sholichah, 2003:54) yang lebih mengarah pada keselarasan emosi, antara lain ; individu dapat merasakan dan mengekspresikan emosi secara tepat baik dari macam dan intensitas emosi, individu dapat mengontrol emosi dan menyadari serta menerima apa yang dirasakan, dan memiliki pembendaharaan kata yang banyak untuk menjelaskan ketika muncul emosi kualitas khusus.

h. Karakteristik kematangan emosi menurut Burnham (dalam Sholichah, 2003:55) yang lebih mengarah pada 
kedewasaan emosi, antara lain: menghadapi lingkungan baru, menyesuaikan diri dengan interaksi baru, penyesuaian pada tanggung jawab baru, mengenali kebutuhan yang sebenarnya dan memiliki vitalitas rohani.

i. Karakteristik kematnagan emosi menurut Yusuf (dalam Sholichah, 2003:57) yang lebih mengarah pada kemandirian emosi, antara lain : kematangan memecahkan ketergantungan (sifat kekanak-kanakan), kemandirian perilaku, kemandirian dalam nilai. Sedangkan karakteristik kematangan emosi yang mengarah pada keseimbangan emosi yang berkaitan dalam memberi dan menerima emosi, antara lain : adekuasi emosi (cinta asih, simpati, altruis atau snang menolong) dan mengendalikan emosi (tidak mudah tersinggung, tidak agresif, bersikap potimis dan tidak pesimis). Lebih jauh Yusuf memberi kriteria kematangan emosi yang lebih mengarah pada keluwesan emosi, antara lain : besikap toleran dan merasa nyaman, luwes dalam bergaul, interdependensi dan mempunyai self-esteem, kontrol diri sendiri, perasaan mau menerima dirinya dan orang lain, dan mampu menyatakan emosinya secara kreatif.

Meskipun dari data penelitian menunjukkan tidak ada hubungan antara kematangan emosi dengan kecemasan persalinan pertama pada usia 17-
21 tahun, bukan berarti variabel kematangan emosi tidak penting, karena variabel tersebut memiliki kontribusi pada masalah lain misalnya: adanya keinginan dari individu untuk mau terbuka dalam belajar dan pengalaman hidup, adanya rasa tanggung jawab yang besar atas segala keputusan yang sudah diambil dan adanya keinginan untuk lebih mementingkan orang lain diatas kepentingan pribadi serta mau menjalin hubungan sosial secara lebih luas sehingga persalinan yang akan dihadapi akan terasa jauh lebih ringan beban kecemasannya.

2. Generalisasi dari hasil penelitian ini terbatas pada populasi dimana penelitian dilakukan, yakni terbatas pada ibu yang mengalami persalinan pertama di usia 17-21 tahun di Kecamatan Candi, Sidoarjo saja. Bisa dikatakan ruang lingkup yang tidak terlalu luas terutama terkait dengan subjeknya merupakan keterbatasan dari penelitian ini.

3. Tinjauan dari usia subjek

Jika dilihat dari karakteristik subjek di atas, terutama terkait dengan faktor usia yaitu antara 17-21 tahun, menurut Mappiare (1999:15) bahwa subjek termasuk dalam masa remaja akhir. Begitu pula dengan yang dismapaikan Yusuf (dalam Sholichah, 2003:13) mengemukakan bahwa masa remaja akhir adalah masa usia 17 sampai 21 tahun. Secara psikologis masa ini merupakan permulaan masa dewasa yang mana emosinya mulai stabil dan pemikirannya mulai matang. Sedangkan menurut Hurlock (2002:246, 249) subjek pada usia 17-21 tahun masuk dalam masa 
dewasa dini, dimana pada masa ini merupakan masa ketegangan emosional. Pada masa ini ketika seseorang melihat sesuatu yang tidak disukai ingin segera merubah sesuai dengan keinginannya. Apabila ketegangan emosi ini terus belanjut, hal umum yang nampak adalah bentuk keresahan. Keresahan ini tergantung dari masalah-masalah penyesuaian diri yang harus dihadapi saat itu dan berhasil tidaknya mereka dalam upaya penyelesaian itu.

Menurut Cattel (dalam Alwisol, 2009:248) bahwa tahap kemasakan atau kematangan emosi adalah pada usia 23-50 tahun, dimana secara umum pada tahap ini ditandai dengan kesibukan, kebahagiaan dan produktivitas. Pada penelitian ini, sampel yang diambil adalah ibu yang melahirkan pertama kali di usia 17-21 tahun, sehingga bisa dikatakan pada usia ini masih belum masuk ke tahap kemasakan. Namun begitu ada beberapa subjek yang tidak merasakan kecemasan yang berarti di usia ini, sehingga bisa dikatakan tidak ada hubungan antara usia yang dijadikan patokan kematangan emosi dengan tingkat kecemasan persalinan pertama.

Dari pembahasan para tokoh di atas, jika dikaitkan dengan penelitian ini dapat disimpulkan bahwa adanya perbedaan pengklasifikasian usia ini didasarkan atas beberapa karakter yang dimunculkan dan hal ini bisa menjadi bahan pertimbangan peneliti untuk bisa menggali lebih dalam dan mencari data dari subjek secara lebih luas lagi terkait dengan kematangan emosinya.

Tidak adanya hubungan antar kematangan emosi dengan kecemasan persalinan pertama pada usia 17-21 tahun dapat pula dianalisa melalui analisis butir pada angket yang telah diberikan kepada subyek. Dari hasil analisis butir didapatkan hasil yabng dapat dijelaskan dibawah ini.

Freud berpendapat bahwa sumber ancaman terhadap ego tersebut dapat berasal dari dorongan yang bersifat insting-insting dari id dan tuntutan-tuntutan dari superego. Pada umumnya, sebagian besar orang mengabaikan sisi kebutuhan psikis ibu saat menjelang persalinan dan lebih memperhitungkan kesiapan fisik belaka (Kartono, 2000:39). Akan tetapi pada tabel 4.11 menggambarkan bahwa seluruh subjek (100\%) menyetujui pernyataan mengenai kemampuan untuk berkomunikasi secara efektif, yang menyebutkan bahwa setiap apapun yang dirasakan oleh para ibu ketika menjelang persalinan selalu disampaikan kepada suaminya. Hal ini lebih mendukung ke arah kebutuhan psikis ibu.

Uniknya para subjek juga menyetujui pernyataan-pernyataan yang menyatakan kalau mereka tidak menganggap penting adanya suatu komunikasi dan tanggung jawab. Mereka menyetujui pernyatan yang menyebutkan bahwa dengan adanya proses persalinan itu adalah suatu hal menyulitkan atau memberatkan. Hal ini bisa dilihat dari pernyataanpernyataan berikut:

1. "Bagi saya berbicara dari hati ke hati itu sangat tidak penting" disetujui $100 \%$ responden.

2. "Kehadiran anak saat ini akan menambah beban tanggung jawab sebagai orang tua." Disetujui sebesar $100 \%$.

3. "Terhadap orang tua yang menelantarkan anaknya, saya diam aja." Disetujui sebesar 100\% juga. 
Sebenarnya kondisi faktual ini sesuai dengan teori Freud (Dalam Arnot, 2006:97) yang mengemukakan bahwa lemahnya ego akan menyebabkan ancaman yang memicu munculnya kecemasan. Jadi sebaik dan seberat apapun komnikasi yang dijalin dan tanggung jawab yang harus dipikul nantinya tidak membuat mereka mengalami kecemasan tetapi dukungan psikis suami yang membuat mereka lebih tenang menghadapi persalinannya. Selain itu perlu ditekankan bahwa dalam menciptakan komunikasi yang efektif seharusnya dalam kondisi yang tenang dan kondusif, tidak dalam kondisi panik atau tegang sebab kondisi menjelang persalinan sang ibu merasakan perasaan yang bercampur aduk. Sehingga dapat disimpulkan jika kemampuan ibu berkomunikasi efektif tidak banyak mempengaruhi kondisi kecemasan pra persalinan pertamanya. Hal ini dimungkinkan oleh adanya beberapa faktor eksternal yang mungkin mempengaruhi pilihanpilihan responden tersebut, misalnya demografi atau latar belakang psiko sosial responden dan keluarga responden.

Kemungkinan kesan tidak maksimalnya komunikasi dengan suami karena suami mereka selalu menghargai sikap sang istri mengenai segala hal yang terkait dengan persalinan pertama mereka. Hal ini dijelaskan oleh pernyataan aitem nomor 51 (saya selalu berusaha berpikir positif) angket kematangan emosi (tabel 4.11) yang disetujui 91,67\% subjek penelitian.

Pertanyaan

berikutnya mengapa suami menghargai sikap istri mengenai persalinan bayi mereka nantinya sehingga terkesan tidak perlu adanya komunikasi secara efektif? Hal ini dimungkinkan karena faktor pendidikan istri yang cukup tinggi. Sehingga pengetahuan dan media informasi-informasi yang dapat diakses dan diterima istri menjadi lebih luas, beragam, dan pemikiran mereka bisa lebih logis. Pada tabel 4.5 mengenai pendidikan istri dijelaskan, $66,6 \%$ istri sudah menempuh jenjang pendidikan SLTA dan sederajat dan bahkan $14,7 \%$ atau sekitar 7 ibu dari total subjek sudah mengenyam pendidikan diploma. Hal ini menunjukkan bahwa dengan tingginya tingkat pendidikan sang istri membuat suami yakin akan keselamatan dan kepastian pilihan terbaik yang sesuai menurut sang istri dalam persiapan persalinannya. Sehingga suami terkesan tidak perlu menjalin hubungan komunikasi secara intens atau sedikit memberi masukanmasukan terhadap persiapan pra persalinan anak pertama mereka. Tingkat pendidikan istri mempengaruhi kepercayaan dan penghargaan suami tentang sikap istri (Kartono, 2000:52).

Jika dikaitkan dengan tabel analisis butir kecemasan persalinan pertama, justru ciri psikis tidak menjadi urutan teratas aitem yang banyak disukai oleh responden, meskipun pada urutan selanjutnya terlihat mendominan. Pada tabel tersebut terlihat ciri perilaku yang banyak dipilih, yaitu "Mendengar pengalaman orang lain membaut saya lebih siap menghadapi persalinan" disetujui $95,8 \%$ responden dan pernyataan "Pikiran saya tidak menentu saat melihat pasien lain yang akan melahirkan masuk ruang persalinan" disetujui 91,67\% responden. Hal ini menunjukkan bahwa kecemasan psikis tidak menjadi kebutuhan yang penting dibandingkan dengan kebutuhan kematangan emosi yang mengarah pada kebutuhan psikis. 
Selain menggunakan analisis butir, dari hasil wawancara yang dilakukan oleh peneliti terhadap 48 subjek yang digunakan untuk menggali lebih jauh faktor-faktor lain ynag dapat mengurangi kecemasan pada subjek terdapat beberapa variasi jawaban. Jawaban dari para subjek dikategorikan berdasarkan jawaban tertinggi (terbanyak) sampai pada jawaban terendah.

Tabel 1

Hasil Wawancara Faktor Penyebab Kecemasan

\begin{tabular}{|c|c|c|c|}
\hline $\begin{array}{l}\mathbf{N} \\
\mathbf{0}\end{array}$ & $\begin{array}{c}\text { Hasil } \\
\text { Wawancar } \\
\text { a }\end{array}$ & $\begin{array}{c}\text { Jumla } \\
\mathbf{h}\end{array}$ & $\begin{array}{c}\text { Prosenta } \\
\text { se }\end{array}$ \\
\hline 1 & $\begin{array}{l}\text { Tidak bisa } \\
\text { melahirkan } \\
\text { normal }\end{array}$ & 8 & $17 \%$ \\
\hline 2 & $\begin{array}{l}\text { Dukungan } \\
\text { keluarga }\end{array}$ & 7 & $15 \%$ \\
\hline 3 & $\begin{array}{l}\text { Tingkat } \\
\text { religiusitas }\end{array}$ & 6 & $13 \%$ \\
\hline 4 & $\begin{array}{l}\text { Persiapan } \\
\text { dana } \\
\text { persalinan }\end{array}$ & 5 & $10 \%$ \\
\hline 5 & $\begin{array}{l}\text { Pengalama } \\
\text { n orangtua } \\
(\mathrm{Ibu})\end{array}$ & 5 & $10 \%$ \\
\hline 6 & $\begin{array}{l}\text { Penyuluhan } \\
\text { Dokter/Bid } \\
\text { an }\end{array}$ & 4 & $8 \%$ \\
\hline 7 & $\begin{array}{l}\text { Informasi } \\
\text { dari media } \\
\text { massa }\end{array}$ & 4 & $8 \%$ \\
\hline 8 & $\begin{array}{l}\text { Senam } \\
\text { Hamil }\end{array}$ & 3 & $7 \%$ \\
\hline 9 & $\begin{array}{l}\text { Kematanga } \\
\text { n emosi }\end{array}$ & 2 & $4 \%$ \\
\hline 10 & $\begin{array}{l}\text { Melahirkan } \\
\text { anak cacat }\end{array}$ & 2 & $4 \%$ \\
\hline 11 & Stres & 1 & $2 \%$ \\
\hline 12 & $\begin{array}{l}\text { Budaya / } \\
\text { adat istiadat }\end{array}$ & 1 & $2 \%$ \\
\hline & Jumlah & 48 & $100 \%$ \\
\hline
\end{tabular}

Kehamilan di trimester ketiga pasti menyebabkan metabolisme tubuh meningkat $10 \%$ hingga $25 \%$ dari keadaan normal. Ibu hamil akan merasa cemas karena semakin dekatnya proses persalinan. Perasaan itu berasal dari perubahan metabolik dan pikiran ibu hamil. Perubahan yang tidak kentara ini berlanjut pada setiap trimester. Pada trimester pertama, ibu hamil merasa lelah. Ibu hamil akan merasa gembira dan sangat bersemangat pada trimester kedua dan ibu hamil akan merasa cemas dan tak sabar pada trimester ketiga (Stoppard, 2003:59). Hal ini terkadang merupakan pengalaman yang tidak menyenangkan atau menyakitkan. Selama kehamilan, ibu mengalami perubahan fisik yang terjadi akibat perubahan hormon dan perasaan cemas. Begitu pula dengan perubahan besar pada badan ibu, misalnya janin yang terlalu besar karena gizi ibu yang berlebihan sehingga membuat perut ibu membesar yang dapat menimbulkan masalah pada kesehatan ibu. Hal tersebut mengakibatkan kekurangmampuan ibu dalam melakukan tanggung jawab yang fisiologis yang menyebabkan kecemasan menghadapi persalinan. Hal ini pula yang terkadang menjadi salah satu penyebab ibu tidak bisa melahirkan secara normal selain adanya faktor lain seperti persalinan kurang bulan, tekanan darah di atas normal, pendarahan hebat, tegang, dan lain sebagainya. Hampir semua faktor penyebab ibu tidak bisa melahirkan secara normal diawali dari kecemasan yang berlebihan yang dialami ibu menjelang persalinan (Obstetri Fisiologi, 2000:210).

Selain faktor fisik, faktor psikis juga tidak kalah pentingnya mendapat perhatian dalam mengurangi kecemasan pada persalinan pertama 
ibu. Menurut Freud, sumber ancaman terhadap egog tersebut dapat berasal dari dorongan yang bersifat instinginsting dari id dan tuntutan-tuntutan dari superego. Hal senada juga diungkapkan oleh Kartono (2001:76) dan Kalil, dkk. (2000:124) bahwa pada usia kandungan tujuh bulan ke atas, tingkat kecemasan ibu hamil semakin akut dan intensif seiring dengan mendekatnya kelahiran bayi. Pada umumnya, sebagian besar orang mengabaikan sisi kebutuhan psikis ibu saat menjelang persalinan dan lebih memperhitungkan kesiapan fisik belaka. Namun demikian faktor psikis selama ini belum mendapatkan perhatian oleh penolong persalinan, hal ini sesuai dengan pendapat Kartono (2000:192) yang menyatakan ahwa para dokter dan bidan hampirhamnpir tidak mempunyai waktu untuk memperhatikan kondisi psikis wanita tersebut, sebab mereka biasanya disibukkan oleh faktor-faktor somatis (jasmaniah). Selain itu kondisi psikis ibu, seperti timbulnya rasa ragu sebagai calon ibu. Calon ibu sering mendengarkan dan mempercayai cerita-cerita yang bukan-bukan mengenai persalinan.

Adanya dukungan keluarga baik dari suami maupun keluarga diprediksi mampu mengurangi tingkat kecemasan ibu, meskipun tidak semua mengalaminya. Menurut Enkin (dalam Asuhan Esensial Persalinan, 2007:5253), dukungan dan pendampingan suami dan anggota keluarga yang lain terhadap ibu selama persalinan dan proses kelahiran bayinya sangat penting. Suami dan keluarga diharapkan dapat berperan aktif dalam mendukung dan mengenali berbagai upaya yang mungkin sangat membantu kenyamanan ibu juga menghargai keinginan ibu untuk menghadirkan teman atau saudara yang secara khusus diminta untuk menemaninya. Hasil persalinan yang baik ternyata erat hubungannya dengan dukungan dari keluarga yang mendampingi ibu selama proses persalinan (Enkin, et al dalam Asuhan Esensial Persalinan, 2007:770. Banyak hal yang bisa dilakukan suami atau keluarga antara lain:

1. Mengucapkan kata-kata yang membesarkan hati dan memberikan pujian kepada ibu.

2. Membantu ibu bernafas secara benar pada saat kontraksi.

3. Memijat punggung, kaki atau kepala ibu dan tindakan-tindakan bermanfaat lainnya.

4. Menyeka muka ibu secara lembut.

5. Menciptakan suasana kekeluargaan dan rasa aman.

6. Menjadi teman bicara yang menyenangkan.

7. Memberikan dukungan dan semangat selama persalinan dan melahirkan bayinya.

8. Menentramkan hati ibu dan tawarkan bantuan jika diperlukan.

Dukungan keluarga juga mempunyai andil yang besar dalam menentukan status kesehatan ibu. Ibu hamil pertama sangatlah memerlukan dukungan dari keluarga. Oleh karena ini merupakan pengalaman pertama bagi ibu hamil dalam menjalani masamasa kehamilan, menghadapi kelahiran dan menjadi calon ibu. Jika seluruh keluarga mengharapkan kehamilan, mendukung bahkan memperlihatkan dukungannya, ibu hamil tersebut akan lebih bahagia dan siap dalam menjalani kehamilan, persalinan dan masa nifas. Dukungan sosial yang berupa pengertian terhadpa calon ibu dari dokter, keluarga dan teman-teman dekat sangat diperlukan (Obstetri Fisiologi, 2000:212). Bentuk lain dukungan yang bisa diberikan oleh suami kepada istrinya yang akan 
menghadapi persalinan pertamanya antara lain:

1. Bentuk dari dukungan emosional ini seperti membuat istri memiliki perasaan nyaman, yakin diperdulikan dan dicintai oleh suami.

2. Bentuk dukungan informasionalnya dapat berupa pemberian informasi, saran atau umpan balik tentang situasi dan kondisi kehamilan sang istri.

3. Lain lagi dengan bentuk dukungan instrumental, dukungan ini lebih berupa penyediaan instrumen, benda-benda, atau materi yang diperlukan untuk masa-masa persalinan yang akan dihadapi sang istri, seperti dana persalinan, pakaian dan perlengkapan bayi, dan materi lain yang dapat menentramkan perasaan istri dari berbagai kecemasan yang ia rasakan.

4. Dukungan penghargaan disini dapat berarti upaya-upaya seperti penghargaan positif pada istri, pemberian semangat, dan persetujuan pada pendapat yang dikemukakan oleh istri. Semua ini bertujuan untuk meningkatkan kepercayaan diri dan membangun harga diri juga kompetensinya sebagai calon ibu.

Adalah satu hal yang sangat positif, jika suami bisa ikut hadir saat proses kelahiran. Kehadiran suami ini, walau sekadar menemani, memegang tangan istri dan membisikkan katakata penghibur kepada istri, akan memberikan dorongan kekuatan mental ekstra bagi istri. Walaupun tak dapat mengurangi rasa sakit, namun kekuatan mental yang diperoleh istri akan membuatnya lebih kuat menahan sakit, yang pada akhirnya akan mempermudah proses kelahiran (dalam Rezky, 2010:92).

Faktor religiusitas seorang ibu juga merupakan salah satu faktor penyebab kecemasan pada persalinan pertama. Menurut Nashori (dalam Rezky, 2010:94) mengatakan bahwa orang-orang religius akan selalu mencoba patuh terhadap ajaran-ajaran agama, menjalankan ritual agama, menyakini doktrin-doktrin agama, beramal dan selanjutnya merasakan pengalaman-pengalaman beragama. Sikap religius adalah keadaan dalam diri seseorang dalam merasakan dan mengakui adanya kekuatan tertinggi yang menaungi kehidupan manusia dengan cara melaksanakan semua perintah Tuhan sesuai dengan kemampuan dan meninggalkan seluruh larangan-Nya, sehingga hal ini akan membawa ketenangan dan ketentraman pada diri. Menurut Meichati (2004:147), kehidupan beragama dapat memberikan kekuatan jiwa bagi seseorang untuk menghadapi tantangan hidup. Agama dapat pula memberikan bantuan moril dalam menghadapi krisis yang dihadapinya. Keyakinan beragama dapat meningkatkan kehidupan itu sendiri ke dalam suatu nilai spiritual. Sehingga menjadikan hidup seseorang bermakna dalam berbagai kondisi, memperoleh ketenangan dalam hidupnya, akan merasakan dan meyakini adanya kekuatan tertinggi yang menaungi kehidupan sehingga akan memberikan kemantapan batin, rasa bahagia dan terlindungi. Pendekatan agama dalam hal ini bukan untuk mengubah keimanan penderita gangguan kecemasan melainkan untuk membangkitkan kekuatan spiritual atau kerohaniannya dalam menghadapi kecemasannya akan masa depan yang dapat melanda dirinya. Jika dikaitkan dengan tujuan 
penelitian ini bahwa ada faktor lain yaitu religiusitas selain kematangan emosi yang dapat mengurangi kecemasan ibu pda persalinan pertama.

Berdasarkan hasil wawancara, terdapat 5 orang responden atau sekitar $10 \%$ dari seluruh responden mengatakan ahwa kecemasan mereka menghadapi persalinan pertama adalah dari segi ekonomi. Bila pasangan suami istri ini termasuk golongan masyarakat menengah keatas, tidak terlalu sulit untuk memikirkan biaya persalinannya kelak. Tetapi berbeda kondisinya dengan mereka yang termasuk dalam tingkat ekonomi menengah kebawah. Bagaimana ibu hamil tersebut memeriksakan kandungan tiap bulannya, bagaimana ibu hamil tersebut mencukupi gizi dengan mengkonsumsi makananmakanan yang begizi, akan tetapi uang tidak ada. Biasanya ibu hamil tersebut hanya pasrah dan menutupi rasa cemasnya dengan berusaha semampunya, meski tidak semua ibu hamil seperti itu.

Adanya pengalaman orangtua khususnya ibu, membuat para calon ibu merasa lebih tenang dan dapat mengurangi kecemasannya. Apalagi ketika proses persalinannya nanti juga didampingi ibunya. Pengalaman, motivasi dan semangat selalu diberikan oleh orang tua sehingga diharapkan akan lancar ketika menjalani proses persalinan. Meskipun tidak semua responden menjadikan pengalaman orang tua sebagai faktor yang mampu mengurangi kecemasan karena adanya faktor jarak dan tempat tinggal sehingga jarang bisa melakukan komunikasi secara intent. Hampir $10 \%$ atau sekitar 5 orang responden setuju dengan hal ini.

Beberapa subjek penelitian menjadikan faktor penyuluhan dokter atau bidan tentang segala hal seputar kehamilan dan persalinan sebagai faktor yang bisa mengurangi kecemasan persalinan pertamanya, yaitu sekitar 4 responden atau $8 \%$ dari seluruh responden. Namun hal ini tidak sepenuhnya merupakan kondisi yang ideal, karena tidak semua subjek dalam penelitian ini selalu memeriksakan kehamilan dan memilih bidan atau dokter sebagai tempat rujukan bersalin. Ada beberapa subjek yang lebih percaya kepada dukun bayi, hal ini dikarenakan adanya faktor kebiasaan atau budaya di daerah tempat mereka tinggal yang melakukan hal tersebut.

Kemajuan teknologi membuat informasi yang diterima semakin banyak dan mudah untuk diakses, seperti koran masuk desa, majalah, radio, televisi bahkan fasilitas internet. Informasi seputar kehamilan dan persalinan membuat sebagian subjek memahami segala hal ynag bisa mengurangi kecemasan persalinan, sehingga mereka cenderung lebih siap dan tenang dalam menghadapi persalinan pertamanya.

Penelitian tentang "Senam Hamil" pernah dilakukan oleh Ristinia dari Universitas Airlangga Surabaya, dimana hasil penelitiannya adalah bahwa senam hamil membawa dampak positif dalam menyeimbangkan kondisi psikologis ibu hamil, terutama pada kehamilan pertama dan berlanjut pada proses persalinannya. Senam hamil membantu para ibu hamil untuk membuat persiapan dalam melahirkan bayinya. Menurut penelitian dikatakan bahwa para ibu hamil harus siap secara mental dan fisik untuk proses alamiah ini. Dengan diberikannya latihan kepada para ibu hamil akan memberikan keyakinan yang lebih besar bahwa proses melahirkan 
bukanlah hal yang menakutkan, mencemaskan, dan sebagainya.

Menurut

Kushartanti

(2004:114), latihan-latihan yang dilakukan pada saat mengikuti senam hamil diantaranya:

1. Pemanasan

2. Latihan kebugaran

3. Latihan penguatan dan peregangan

4. Latihan relaksasi

5. Latihan pernafasan

6. Latihan koreksi sikap

7. Latihan pendinginan.

Hal ini pula yang dilakukan oleh sekitar 3 orang subjek penelitian ini untuk mengurangi kecemasan. Namun karena senam hamil ini relatif mahal sehingga tidak semua mengambil langkah ini untuk mengurangi kecemasannya. Dan tidak menutup kemungkinan pula mereka yang sudah melakukan senam hamil secara otomatis kecemasan pada saat persalinan akan berkurang. Adanya faktor lain seperti pendampingan suami, sarana transportasi, dan lainlain terkadang justru bisa meningkatkan kecemasan.

Ternyata faktor kematangan emosi berdasarkan hasil wawancara hanya memberikan kontribusi yang sedikit dalam menurunkan kecemasan ibu pada persalinan pertamanya. Hanya sekitar 2 orang atau $4 \%$ dari seluruh jumlah subjek yang menjadikan faktor kematangan emosi yang bisa mengurangi kecemasan persalinan pertamanya.

Stressor adalah sebuah keadaan atau kondisi yang dapat menimbulkan stres (pencetus stres). Bila ibu yang akan menjelang persalinan telah stres, pastilahada kecenderungan untuk cemas. Cemas itu timbul akibat adanya respon terhadap kondisi stres atau konflik. Stres yang terjadi pada ibu yang akan mealui proses persalinan dapat mempengaruhi lancar tidaknya persalinan yang akan dijalani. Janin dapat mengalami keterlambatan perkembangan atau gangguan emosi pada saat lahir nanti jika stres ibu tidak ditangani dengan baik. Hal ini menjadi alternatif pilihan responden, meskipun hanya satu orang saja atau sekitar 2\% dari jumlah responden.

Begitu pula dengan faktor budaya yang diutarakan oleh seorang responden. Pada budaya-budaya tertentu, sebagai contoh di Bali, menganjurkan ibu untuk tidak mengkonsumsi daging sapi, lele atau hewan yang bagi budaya disana ganas dan suci, hal tersebut dapat menjadikan anak suka marah dan nakal. Padahal makanan tersebut merupakan makanan yang bermanfaat bagi ibu hamil dan janin. Selain itu, pasangan suami-istri tidak boleh membunuh binatang ataupun apa saja, karena dapat mengakibatkan hal-hal yang tidak baik bagi anak (janin). Suami dari ibu hamil tidak diperbolehkan memotong rambut dan jenggot. Adapula kepercayaan bahwa minum minyak kelapa dapat memperlancar persalinan karena minyak bersifat licin.

Selain itu tugas baru subjek yang menikah dan menjadi seorang ibu muda yang harus melewati fasefase kehamilan dan menghadapi persalinan apalagi untuk yang pertama kalinya, tentu membawa pengaruh terhadap faktor kecemasannya. Menurut Mappiare (dalam Sholichah, 2003:16), salah satu aspek perkembangan remaja akhir adalah terkait dengan faktor kecemasannya. Keadaan emosi yang mencemaskan secara umum timbul dari kecemasan yang berkelanjutan. Pada masa ini remaja akan mengalami kecemasan ketika belajar untuk memainkan 
peranan-peranan seks baru. Remaja juga mengalami kecemasan dalam dirinya dan lingkungan situasi-situasi sosial dimana remaja tersebut berada yang menuntut perhatian yang sangat kuat. Hal inilah yang membuat peneliti ingin mengetahui seberapa besar tingkat kecemasan yang ditimbulkan ketika menghadapi persalinan pertamanya jika dikaitkan dengan kematangan emosinya.

Mayoritas subjek memiliki tingkat kematangan emosi yang sedang $(47,92 \%)$ dan tinggi $(31,25 \%)$. Hanya $20,83 \%$ subjek yang memiliki tingkat kematnagan emosi dalam kategori yang rendah. Tetapi tingginya prosentase kematangan emosi tersebut tidak menggambarkan adanya pengaruh yang signifikan terhadpa kecemasna ibu dalam menghadapi persalinan pertamanya karena walaupun $31,25 \%$ responden berada dalam kategori kecemasan persalinan pertama rendah, tetapi masih ada sekitar 47,92\% subjek berkategori mengalami kecemasan cukup, dan bahkan ada 20,83\% berkategori kecemasan tinggi.

Jika walaupun secara statistik menunjukkan kalau kematangan emosinya tinggi tapi ternyata tidak mempengaruhi kecemasan para subjek. Karena pernyataan-pernyataan yang tidak mendukung hipotesis awal peneliti masih termasuk dalam pernyataan yang paling banyak disetujui oleh para subjek. Tapi meskipun begitu secara umum dapat disimpulkan kematangan emosi responden tergolong tinggi dan kecemasannya sebagian besar tergolong rendah, akan tetapi tetap ada responden yang memiliki kecemasan tinggi karena ada faktor-faktor lain yang mempengaruhi hubungan antara kedua variabel ini sehingga antara variabel independent tidak benar- benar mempengaruhi variabel dependent.

Ditolaknya hipotesis yang diajukan oleh peneliti menunjukkan bahwa meskipun subjek memiliki kematangan emosi sangat tinggi, tingkat kecemasan ibu pada persalinan anak pertamanya tidak dapat diprediksi. Ada sebagian subjek yang rendah, tetapi juga ada sebagian yang tinggi.

\section{Simpulan}

Berdasarkan hasil penelitian dan pembahasan yang telah dilakukan, maka dapat disimpulkan bahwa :

1. Tidak ada hubungan yang signifikan antara kematangan emosi dengan kecemasan persalinan pertama, sehingga tingginya kematangan emosi tidak serta merta menurunkan kecemasna ibu pada persalinan pertamanya, dan sebaliknya. Hal ini juga didukung dengan hasil analisis korelasi product moment dimana diperoleh hasil koefisien korelasi $\mathrm{r}_{\mathrm{xy}}=-0,167$ dengan $\mathrm{p}$ $(0,257)>0,05$. Artinya hubungan kedua variabel tersebut tidak signifikan (tidak ada hubungan).

2. Kecemasan pada persalinan pertama sebagian besar subjek tergolong cukup dan bergerak kearah rendah dan sangat rendah, namun masih ada sebagian subjek yang mengalami kecemasan dan intensitas yang tinggi. Sehingga dengan tingginya dua variabel bebasnya tidak benar-benar mempengaruhi variabel tergantung dengan signifikan.

3. Dukungan pula dengan hasil wawancara dari beberapa subjek yang terkait dengan penelitian yang dilakukan, menyebutkan bahwa bukan hanya faktor kematangan emosi saja yang 
mempengaruhi tinggi rendahnya kecemasan seseorang dalam proses persalinan pertamanya, tetapi juga adanya faktor-faktor diluar variabel penelitian yang dapat mempengaruhi hasil penelitian seperti faktor sosial (seperti pengaruh pendidikan atau pengajaran, dan berbagai tekanan sosial), faktor demografik, latar belakang psikososial istri, faktor intelektual atau latar belakang pendidikan istri, faktor pengalaman psikis, faktor lingkungan sosial, budaya, dukungan keluarga terutama suami dan ibu, informasi tentang kehanmilan dan persalinan yang bisa mereka dapatkan dari media massa cetak dan elektronik serta internet yang bisa diakses dengan mudah, keikutsertaan beberapa dari mereka yang mengikuti kelompok senam hamil, pengarahan dari petugas posyandu dan puskesmas setempat tentang persiapan persalinan, tingkat religiusitas dan ekonomi. Kesemuanya itu merupakan faktor lain yang juga membuat rendah tingkat kecemasan menghadapi persalinan pertama pada usia 1721 tahun.

\section{Saran}

Berdasarkan hasil penelitian yang telah dilakukan, maka saran yang dapat dikemukakan dan yang memungkinkan untuk dipertimbangkan pelaksanaannya adalah sebagai berikut:

1. Bagi Subjek Penelitian

Disarankan agar lebih mempersiapkan diri terlebih dahulu baik secara fisik dan psikis, agar bila menjalani proses persalinan nantinya tidak menghadapi kecemasan yang berlebihan. Caranya dengan mengatur usia perkawinan dan juga mengatur usia kehamilan agar nantinya jika menghadapi proses kehamilan tersebut dirinya sudah siap. Selain itu dianjurkan juga untuk tetap menjaga pola makan, tidak merokok, membiasakan berjalan berkeliling kompleks jika tidak mengikuti senam hamil agar melatih pernafasan, mempersiapkan fisik, mental, dan ekonomi untuk menghadapi persalinan.

2. Bagi Rumah Bersalin atua Puskesmas.

Untuk mengadakan penyuluhan mengenai permasalahan yang muncul sehubungan dengan penyelenggaraan perkawinan dan persalinan bagi para calon pengantin. Hal ini bisa dibantu dengan lembaga lainnya, seperti LSM.

3. Bagi Bidan

Disarankan juga bagi para bidan yang berhubungan langsung dengan para ibu muda agar lebih memperhatikan keadaan psikologis dan fisiologis pasiennya, terutama yang terkait dengan kematangan emosi pasien. Hal ini bertujuan agar dapat diketahui dengan segera bila ada salah satu ibu muda yang menunjukkan kecemasan yang tinggi, sehingga dapat ditangani sesegera mungkin.

4. Bagi Peneliti Selanjutnya

Karena tidak signifikannya hasil penelitian ini walaupun secara kasat mata dan non empiris terlihat adanya hubungan yang negatif antara kematangan emosi terhadap kecemasan ibu pada persalinan pertama, namun secara statistikal terbukti nir signifikan. 
Sehingga untuk peneliti selanjutnya alangkah baiknya untuk meneliti faktor-faktor yang dimungkinkan mempengaruhi hubungan variabel-variabel tersebut, seperti faktor sosial (seperti pengaruh pendidikan atau pengajaran, dan berbagai tekanan sosial), faktor demografik, latar belakang psikososial istri, faktor intelektual atau latar belakang pendidikan istri, faktor pengalaman psikis, faktor lingkungan sosial, budaya, dukungan keluarga terutama suami dan ibu, informasi tentang kehamilan dan persalinan yang bisa mereka dapatkan dari media massa cetak dan elektronik serta internet yang bisa diakses dengan mudah, keikutsertaan beberapa dari mereka yang mengikuti kelompok senam hamil, pengarahan dari petugas posyandu dan puskesmas setempat tentang persiapan persalinan, tingkat religiusita, ekonomi dan lain sebagainya.

Atau peneliti lain dapat meneliti variabel-variabel lain yang terkait dengan kematangan emosi atau kecemasan persalinan pertama. Selain itu juga dapat meneliti lebih dalam lagi yang terkait dengan kecemasan sebelum terjadinya persalinan atau pra persalinan.

\section{Daftar Pustaka}

Arikunto, S. 2006. Prosedur Penelitian Suatu Pendidikan Praktik. Jakarta: Rineka Cipta. 2007. Manajemen Penelitian. Jakarta : Rineka Cipta.
Alwisol. 2009. Psikologi Kepribadian. Malang: UMM Press.

Asuhan Persalinan Normal. 2007. Asuhan Esensial Persalinan. Buku Acuan. Tim Revisi.

Arnot. 2006. Psychology for Better Living. New York: Jhon Wiley and Sons Inc.

Azwar, S. 2009. Reliabilitas dan Validitas. Yogyakarta: Pustaka Pelajar.

2007. Penyusunan Skala

Psikologi. Yogyakarta: Pustkaa Pelajar.

2009. Metode Penelitian. Yogyakarta: Pustaka Pelajar.

Yogyakarta: Pustaka Pelajar.

Chaplin, J.P. 2008. Kamus Lengkap Psikologi. Penerjemah : Kartini Kartono. Jakarta: PT. Raja Grafindo Persada.

Corey, Gerald. 2003. Teori dan Praktek Konseling dan Psikoterapi. Bandung: Refika.

Cyrillia. 2006. Emosi Dalam Kehidupan. Jakarta: Paramadina.

Danuatmaja, Bony dan Meliasari, M., 2001. Persalinan Normal Tanpa Rasa Sakit. Jakarta: Puspa Swara.

Data Kesehatan Dinas Propinsi Jawa Timur, 2008.

Data Badan Pusat Statistik (BPS) Kabupaten Sidoarjo, 2009. 
Dariyo, A. 2003. Psikologi Perkembangan Dewasa Muda. Jakarta: Gramedia Widiasarana Indonesia.

Feinberg, Mortimer R. Ph.D. 2004. Mengenali Tanda-tanda Kematangan Diri. (On Line) http://tempatkita.blogspot.com (diakses 27 Maret 2010).

Ghufron, Nur. 2010. Teori-teori Psikologi. Yogyakarta: Ar-Ruzz Media.

Hadi, S. 2004. Statistik I dan II. Yogyakarta: Andi Offset.

Hall, C.S. \& Lindzey, G. 2000. Teoriteori Psikodinamik (Klinis). Alih Bahasa: A. Supratiknya. Yogyakarta: Kanisius.

Hurlock, E. 2002. Psikologi Perkembangan. Jakarta: Erlangga.

Jameson. 2003. Psychology of Adolescence. Englewood Cliffs America: Prestice Hall Inc.

Januadi, E.J. 2004. Mempersiapkan Persalinan Sehat. Jakarta: Puspa Swara.

Kaplan, H. I., Sadock, B.J., \& Grebb, J. A. 1999. Sinopsis Psikiatri Jilid 2. Alih Bahasa: Widjaja Kusuma. Jakarta: Binarupa Aksara.

Kartono, Kartini, 2000. Psikologi Wanita Jilid 2. Bandung: Mandar Maju.

Kerlinger, F.N. 2004. Asas-asas Penelitian Behavioral, Edisi
Revisi. Yogyakarta: Gadjah Mada University Press.

Kushartanti. 2004. Senam Hamil Menyamankan Kehamilan Mempermudah Persalinan. Yogyakarta: Lintang Pustaka.

Lahey \& Cininero. 2001. Emosional and Adaption. New York: Exford Univercity Press.

Maimunah, Siti. 2005. Kamus Istilah Kebidanan. Jakarta: EGC.

Manuaba, Ida Bagus Gde. 2000. Ilmu Kebidanan, Penyakit Kandungan dan Keluarga Berencana untuk Pendidikan Bidan. Jakarta : EGC.

Maramis, W.F. 2001. Ilmu Kedokteran Jiwa. Surabaya: Airlangga Univesity Press.

Mappiare, Andi. 1999. Psikologi Orang Dewasa. Surabaya: Usaha Nasional.

Remaja. Surabaya: Usaha Nasional.

Meichati. 2004. Kepribadian Keluarga. Yogyakarta: Kanisius.

Nazir, Mohammad. 2009. Metode Penelitian. Jakarta: Ghalia Indonesia.

Obstetri Fisiologi. 2000. Sinopsis Obstetri, Obstetri Patologi Jilid 1. Jakarta: Buku Kedokteran EGC.

Puspitasari, Endah dan Sartini Nuryoto. 2002. Penerimaan Diri pada Lanjut Usia Ditinjau dari Kematnagan Emosi. Jurnal 
Psikologi Universitas Gajah Mada. Vol. 29 No. 2 Desember 2002. (online)

http://psikologi.ugm.ac.id/

(diakses 30 Maret 2010).

Ramaiah, S. 2003. Kecemasan, Bagaimana Mengatasi

Penyebabnya. Jakarta : Pustaka Populer.

Rezky. 2010. Hubungan Antara Dukungan Suami dan Tingkat Religiusitas Istri Terhadap Kecemasan Persalinan Anak Pertama. Skripsi. Universitas Hang Tuah. Tidak Diterbitkan.

Riwayati, Dwi Yuli. 2006. Perbedaan

Kematangan Emosi pada Wanita Usia 25-35 Ditinjau dari Tingkat Pendidikan dan Usia Memasuki Perkawinan (Penelitian Komparatif pada Ibu-ibu Rumah Tangga di RW 5 Desa Tunahan Kecamatan Keling Kabupaten Jepara Tahun 2006). Skripsi. Universitas Gajah Mada. Tidak Diterbitkan.

Sholichah, Nikmatus. 2003. Hubungan Antara Kecerdasan Spiritual Dengan Kematangan Emosi pada Mahasiswa Psikologi Universitas Putra Bangsa Surabaya. Skripsi. Universitas Putra Bangsa. Tidak Diterbitkan.
Sugiono, 2010. Metode Penelitian Kuantitatif, Kualitatif dan $R \& D$, Bandung: Alfabeta.

Suhartatik, (2004). Hubungan Antara Keajegan Membaca Al-Qur'an dengan Tingkat Kecemasan Menjelang Persalinan di Daerah Kepanjen Malang. Skripsi. Universitas 45 Surabaya. Tidak Diterbitkan.

Susabdo. 2001. Psikologi Remaja Dimensi Perkembangan. Bandung: Mandar Maju.

Stuar \& Sudeen. 2000. Invitation to Psychology. New York: Academic Press.

Stoppard, Miriam. 2003. Buku Pintar Persalinan. Bandung: Alfabeta.

Wangmuba. 2009. Kematangan Emosi (online) http://Wangmuba.com (diakses 15 Maret 2010).

Walgito. 2004. Psikologi Perkembangan. Malang: UMM Press

Young, 2006. Emotion in Man and Animal. Jakarta: Erlangga.

Yusuf, Syamsu. 2000. Psikologi Perkembangan Anak dan Remaja. Bandung: PT. Rosda Karya. 